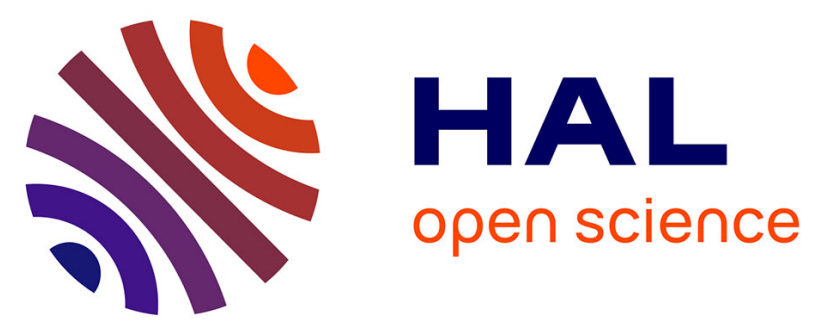

\title{
Towards the Electrochemical Diagnostic of Influenza \\ Virus: Development of Graphene-Au Hybrid Nanocomposite Modified Influenza Virus Biosensor Based on Neuraminidase Activity
}

Ülkü Anik, Yudum Tepeli, Maher Sayhi, Jihene Nsiri, Mohamed Fethi Diouani

\section{To cite this version:}

Ülkü Anik, Yudum Tepeli, Maher Sayhi, Jihene Nsiri, Mohamed Fethi Diouani. Towards the Electrochemical Diagnostic of Influenza Virus: Development of Graphene-Au Hybrid Nanocomposite Modified Influenza Virus Biosensor Based on Neuraminidase Activity. Analyst, 2017, 143 (1), pp.150-156. 10.1039/c7an01537b . pasteur-02020220

\section{HAL Id: pasteur-02020220 \\ https://hal-riip.archives-ouvertes.fr/pasteur-02020220}

Submitted on 15 Feb 2019

HAL is a multi-disciplinary open access archive for the deposit and dissemination of scientific research documents, whether they are published or not. The documents may come from teaching and research institutions in France or abroad, or from public or private research centers.
L'archive ouverte pluridisciplinaire HAL, est destinée au dépôt et à la diffusion de documents scientifiques de niveau recherche, publiés ou non, émanant des établissements d'enseignement et de recherche français ou étrangers, des laboratoires publics ou privés.

\section{(1)(1) $\$(0)$}

Distributed under a Creative Commons Attribution - NonCommercial - ShareAlikel 4.0 


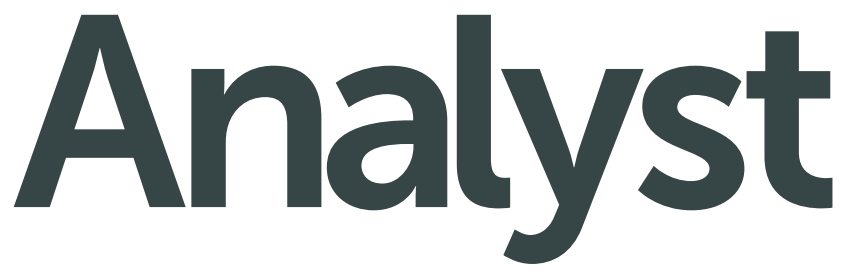

\section{Accepted Manuscript}

This article can be cited before page numbers have been issued, to do this please use: U. Anik, Y. Tepeli, M. Sayhi, J. Nsiri and M. F. Diouani, Analyst, 2017, DOI: 10.1039/C7AN01537B.

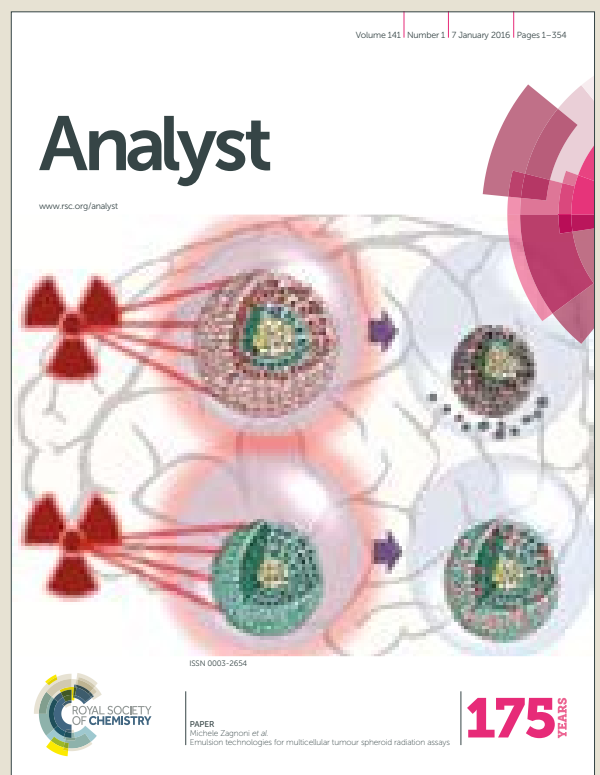

This is an Accepted Manuscript, which has been through the Royal Society of Chemistry peer review process and has been accepted for publication.

Accepted Manuscripts are published online shortly after acceptance, before technical editing, formatting and proof reading. Using this free service, authors can make their results available to the community, in citable form, before we publish the edited article. We will replace this Accepted Manuscript with the edited and formatted Advance Article as soon as it is available.

You can find more information about Accepted Manuscripts in the author guidelines.

Please note that technical editing may introduce minor changes to the text and/or graphics, which may alter content. The journal's standard Terms \& Conditions and the ethical guidelines, outlined in our author and reviewer resource centre, still apply. In no event shall the Royal Society of Chemistry be held responsible for any errors or omissions in this Accepted Manuscript or any consequences arising from the use of any information it contains. 
Received 00th January 20xx, Accepted 00th January 20xx

DOI: $10.1039 / \times 0 \times x 00000 x$

www.rsc.org/

\section{Towards the Electrochemical Diagnostic of Influenza Virus: Development of Graphene-Au Hybrid Nanocomposite Modified Influenza Virus Biosensor Based on Neuraminidase Activity}

\author{
Ülkü Anik*a ${ }^{a}$ Yudum Tepeli ${ }^{a}$, Maher Sayhi ${ }^{b, c}$, Jihene Nsiri ${ }^{b}$, \\ Mohamed Fethi Diouani*b
}

\begin{abstract}
An effective electrochemical influenza A biosensor based on graphenegold $(\mathrm{Au})$ hybrid nanocomposite modified $\mathrm{Au}$-screen printed electrode has been developed. The working principle of the developed biosensor relies on the measurement of neuraminidase (N) activity. After the optimization of experimental parameters like the effect of bovine serum albumin addition, immobilization time of fetuin $A$ and immobilization time of PNA lectin, the analytical characteristics of the influenza A biosensor were investigated. As a result, a linear range between $10^{-8}$ $\mathrm{U} / \mathrm{mL}$ and $10^{-1} \mathrm{U} / \mathrm{mL}$ has been found with relative standard deviation value of $3.23 \%$ (for $10^{-5} \mathrm{U} / \mathrm{mL}$ of $\mathrm{N}, \mathrm{n}: 3$ ) and limit of detection value as $10^{-}$ ${ }^{8} \mathrm{U} / \mathrm{mL} \mathrm{N}$.The developed biosensor has also been applied for real influenza virus $A$ (H9N2) detection and very successful results were obtained.
\end{abstract}

\section{Introduction}

Influenza virus A can be described as a negative stranded RNA virus which belongs to Orthomyxoviridae family. The virus contains two surface glycoproteins namely hemagglutinin $(\mathrm{H})$ and neuraminidase $(\mathrm{N})$. The classification of the virus subtype can be made according to the antigenic properties of these $18 \mathrm{H}(1-18)$ and $11 \mathrm{~N}$ (1-11) glycoproteins $^{1-14}$. Since the influenza virus is very mutagenic, it can easily change the antigenic portions of $\mathrm{H}$ and $\mathrm{N}$ proteins and as a result very serious antigenic drift has been occurred ${ }^{15}$. Seasonal influenza viruses can easily be affected by these antigenic drift mutations which cause millions of serious infections and approximately 500.000 deaths for every year ${ }^{15,16}$. Also, sometimes two or more influenza $A$ viruses of different origin infects the same cell and as a result, new strains or subtypes are emerged because of the occurrence of genetic reassortment ${ }^{1}$. As an example, the reassortment between human and avian virus strains was the reason of influenza A pandemics in 1957 (H2N2) and in 1968 (H3N2) while in 2009 (H1N1) pandemic virus was found to be a reassortant containing gene segments from human, avian and swine influenza viruses ${ }^{2,4}$. Besides these, highly mortal avian viruses like H5N1 and H7N9 have been discovered to transmit from birds to humans ${ }^{4,17}$. Because of these, some researchers define the virus as "continuously emerging infectious disease" which means it still continues to be a threat for animals and human beings ${ }^{15}$.

Although rapid detection of this virus is mandatory, present influenza diagnosis techniques cannot compete with the

\footnotetext{
${ }^{a . a}$ Mugla Sitki Kocman University, Faculty of Science, Chemistry Department, Kotekli/Mugla.

${ }^{b .}$ Laboratory of Epidemiology and Veterinary Microbiology (LEMV), Institut Pasteur de Tunis, University of Tunis El Manar, LR11IPT03, Tunis-Belvédère 1002, Tunisia. c. Faculty of Sciences of Tunis, University of Tunis El Manar, Tunisia.

† Footnotes relating to the title and/or authors should appear here.

Electronic Supplementary Information (ESI) available: [details of any supplementary information available should be included here]. See DOI: $10.1039 / \times 0 \times x 00000 x$
} 
mutagenic behavior of the influenza virus. For example, viral culture, which was accepted as a golden standard method, needs two or three days to retrieve the results which is a kind of long time for the diagnosis of influenza virus ${ }^{18-20}$. On the other hand, quantitative polymerase chain reaction (qPCR), which is chosen frequently by the health personnel can be described as sensitive but relatively slow (took about $2 \mathrm{~h}$ ). qPCR is also expensive and can be performed only with the specialists ${ }^{20-22}$. Apart from these methods, various immune based rapid tests have been fabricated recently to compensate the fast diagnosis need of the virus. From this point of view, these tests manage to show the results in 15 to $30 \mathrm{~min}$. However, on the other hand, they lack off the sensitivity and the precision $20,21,23,24$.

Electrochemical techniques are accepted as practical techniques for many applications ${ }^{25,26}$. The combination of electrochemical techniques with biosensor systems, results with electrochemical biosensors which provide not only practicality but selectivity and sensitivity as well ${ }^{27,28}$. For these reasons, electrochemical biosensors can be accepted as good candidates to be used in point of care systems ${ }^{29}$. Recently electrochemical biosensors were combined with nanomaterials and as a result, more sensitive and accurate results were obtained ${ }^{30-32}$. Graphene is a kind of twodimensional nanomaterial and provides properties like higher surface area and good conductivity which are very important for the electrochemical biosensors ${ }^{33-35}$. Apart from graphene, recently graphene-metallic nanocomposites were produced and used in these systems. These nanocomposites provide more sensitive and selective results when combined with the biosensor systems ${ }^{36-43}$

Considering the influenza biosensors, it can be stated that, up to now almost only $H$ based systems have been developed ${ }^{7-10,44-48}$. Lately our group managed to develop a $\mathrm{N}$ based electrochemical influenza biosensor ${ }^{14}$. In that work, as a preliminary data, only the electrochemical impedance spectroscopy (EIS) diagrams about the fabrication of biosensor were presented ${ }^{14}$. For that earlier work, glassy carbon paste electrode was used as the main electrode. Firstly fetuin A that is a kind of glycoprotein was attached onto the electrode. Then, $\mathrm{N}$ was immobilized onto fetuin A. Fetuin A includes terminal 12-14 sialic acid residues per molecule and $\mathrm{N}$ clevages fetuin $\mathrm{A}$ from this sialic acid ends. Lastly, peanut agglutinin (PNA) lectin was immobilized onto the electrode surface to monitor this cleavage ${ }^{14}$. 


\section{Journal Name}

In this work, as a continuation of our previous paper, we improve our system by using gold screen printed electrode (AuSPE) together with graphene-Au hybrid nanocomposite. Also the experimental parameters about the developed system were optimized and analytical characteristics were examined. Lastly, the developed biosensor was applied for real influenza A virus (H9N2) detection.

\section{Experimental}

\section{Chemicals}

Graphite powder, $\mathrm{NaNO}_{3}$, chloroauric acid $\left(\mathrm{HAuCl}_{4} \cdot \mathrm{H}_{2} \mathrm{O}\right)$, $\mathrm{K}_{3}\left[\mathrm{Fe}(\mathrm{CN})_{6}\right], \mathrm{K}_{4}\left[\mathrm{Fe}(\mathrm{CN})_{6}\right] .3 \mathrm{H}_{2} \mathrm{O}, \mathrm{N}$-(3-Dimethylaminopropyl)- $\mathrm{N}^{\prime}$ ethylcarbodiimide hydrochloride (EDC), N-Hydroxysuccinimide (NHS), fetuin A, bovine serum albumin (BSA), N, PNA lectin, MES monohydrate and ethylene glycol (EG) were purchased from Sigma-Aldrich. $\mathrm{H}_{2} \mathrm{SO}_{4}, \mathrm{H}_{2} \mathrm{O}_{2}, \mathrm{KMnO}_{4}, \mathrm{KH}_{2} \mathrm{PO}_{4}, \mathrm{NaOH}, \mathrm{NaCl}$ and $\mathrm{KCl}$ were obtained from Merck. Double distilled water was used for the preparation of all solutions. All chemicals were of analytical grade and were used without needing further purification.

\section{Instrumentation}

Electrochemical measurements were carried out by using $\mu$ AUTOLAB Type III with the FRA 2 module electrochemical measurement system from Metrohm B.V. that is controlled by NOVA 1.10 software. AuSPE was used as a working electrode and was purchased from Dropsens. SEM and EDS measurements were performed at JSM-7600 F FEG-SEM at $15.0 \mathrm{kV}$. During the preparation procedure of graphene-Au nanocomposite, Thermo Electron Corporation as $\mathrm{pH}$-meter, IKA ${ }^{\circledR}$ C-MAG HS7 hotplate, Bandelin Sonorex sonicator and NUVE vacuum oven were used. For the incubation of biological materials at $37^{\circ} \mathrm{C}$ incubator shaker was used. ELLA measurements were carried out with Automatic plate reader with 490nm filter.

\section{Synthesis procedure of graphene-Au nanocomposite}

In order to synthesize graphene-Au nanocomposite, graphene oxide (GO) was used as the starting material. Therefore, first GO was synthesized by using modified Hummers-Offeman method from graphite ${ }^{38,49}$. For this purpose, $1 \mathrm{~g}$ of graphite powder was added into $23 \mathrm{~mL} 98 \% \mathrm{H}_{2} \mathrm{SO}_{4}$ solution and stirred at room temperature for $24 \mathrm{~h}$. Then, $100 \mathrm{mg}$ of $\mathrm{NaNO}_{3}$ was added into the mixture and stirred for another $30 \mathrm{~min}$. After the mixture was cooled to $5{ }^{\circ} \mathrm{C}$ by using an ice-bath, $3 \mathrm{mg}$ of $\mathrm{KMnO}_{4}$ was added to the medium and then the stirred mixture was heated up to $40{ }^{\circ} \mathrm{C} .46 \mathrm{~mL}$ of double distilled water was added into above mixture during a period of $25 \mathrm{~min}$. Finally, $140 \mathrm{~mL}$ of double distilled water and $10 \mathrm{~mL}$ of $30 \% \mathrm{H}_{2} \mathrm{O}_{2}$ were added into the mixture to stop the reaction. The unexploited graphite in the resulting mixture was removed by centrifugation. Then the mixture was dried in a desiccator at room temperature.

Additionally, for the graphene-Au nanocomposite synthesis step, $10 \mathrm{mg}$ portion of GO powder which was synthesized by modified Hummers-Offeman method was dispersed in $10 \mathrm{~mL}$ of water by sonication for $1 \mathrm{~h}$ to form stable GO colloid ${ }^{50,51}$. Then, $20 \mathrm{~mL}$ of EG solution and $0.5 \mathrm{~mL}$ of $0.01 \mathrm{M} \mathrm{HAuCl}_{4} \cdot \mathrm{H}_{2} \mathrm{O}$ were added to the $\mathrm{GO}$ colloid and stirred for $30 \mathrm{~min}$. After that, the mixture was heated at $100{ }^{\circ} \mathrm{C}$ for $6 \mathrm{~h}$ by applying the magnetic stirring. Subsequently, the graphene-Au nanocomposites were separated from the EG solution via centrifugation and washed with deionized water for five times. The resulting product was dried in a vacuum oven at $60{ }^{\circ} \mathrm{C}$ for $12 \mathrm{~h}^{37}$. Finally, the synthesized graphene-Au nanocompsite was dispersed to $10 \mathrm{mg} / \mathrm{mL}$ in double distilled water by ultrasonication and stored at $4{ }^{\circ} \mathrm{C}$ until it was used ${ }^{38,40,41,52}$.

\section{Preparation of developed electrochemical Influenza A biosensor}

AuSPE was used as the supporting electrode for the preparation of developed electrochemical influenza $A$ biosensor. First, AuSPE was modified with graphene-Au hybrid nanocomposite. For this purpose, $6 \mu \mathrm{L}$ of graphene-Au nanocomposite dispersion $(10 \mathrm{mg} / \mathrm{mL}$, in double distilled water) was dropped onto the surface of AuSPE and dried at room temperature for $1 \mathrm{~h}$. Then, $10 \mu \mathrm{L}$ of $50 \mathrm{mM}$ EDC/NHS mixture (in $50 \mathrm{mM}$ MES pH:5.5 solution) was dropped onto the electrode surface and waited for $1 \mathrm{~h}$. Subsequently, the electrode surface was rinsed with MES and phosphate buffered saline (PBS) with $\mathrm{pH}$ value of $7.4(137 \mathrm{mM} \mathrm{NaCl}, 10$ $\mathrm{mM} \mathrm{KH} \mathrm{PO}_{4}$, and $2.7 \mathrm{mM} \mathrm{KCl}$ ). After that, $10 \mu \mathrm{L}$ of $250 \mu \mathrm{g} / 250$ $\mu \mathrm{L}$ of fetuin $\mathrm{A}$ in $0.1 \mathrm{M}$ PBS was immobilized onto the electrode surface and waited for $30 \mathrm{~min}$. The electrode surface was then washed with PBS and then $10 \mu \mathrm{L}$ of $1 \%$ BSA (in 0.1 PBS) solution was dropped on to electrode surface for performing BSA effect experiments. Other than that, BSA was not used during the fabrication of the influenza $A$ virus biosensor. After that, the electrode was rinsed with PBS and $10 \mu \mathrm{L}$ of different concentrations of $\mathrm{N}$ (in $0.1 \mathrm{M} \mathrm{pH}: 7.4$ PBS) was dropped onto the electrode surface and waited for $18 \mathrm{~h}$ at $37{ }^{\circ} \mathrm{C}$ under the stirring. After the electrode surface was washed with PBS, 10 $\mu \mathrm{L}$ of $50 \mu \mathrm{g} / \mathrm{mL}$ PNA lectin (in $0.1 \mathrm{M} \mathrm{pH}: 7.4$ PBS) solution was 
dropped onto the developed electrochemical biosensor for $1 \mathrm{~h}$ at $+4{ }^{\circ} \mathrm{C}$. PNA lectin here specifically binds to the galactose molecules that appear after $\mathrm{N}$ cleavages the sialic acids from fetuin A molecule. By this way, $\mathrm{N}$ activity of the developed influenza A biosensor was determined electrochemically (Scheme 1). The characterization of the developed electrochemical influenza A biosensor and the determination of $\mathrm{N}$ activity studies were carried out by using EIS method.

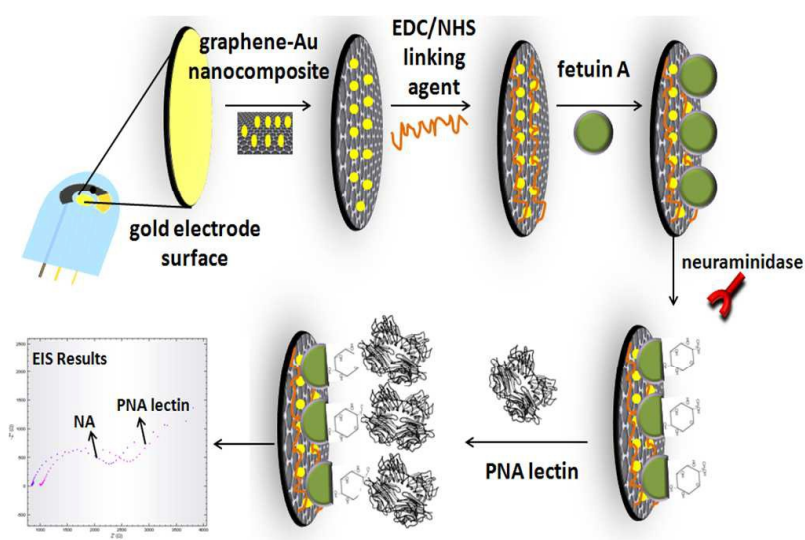

Scheme 1. Schematic diagram depicting the steps of developed electrochemical influenza $\mathrm{A}$ biosensor.

\section{Influenza type A virus replication in embryonated eggs}

H9N2 influenza type A virus (A/Equi/1/Prague 56) was propagated in 11- day old specific-pathogen free (SPF) chicken embryonated eggs via the allantoic route. The eggs were incubated at $37{ }^{\circ} \mathrm{C}$ for three days and the allantoic fluid was collected, clarified by centrifugation at $3000 \times$ for $15 \mathrm{~min}$. Viral titer, in the collected allontoic fluids, was monitored by hemagglutination test.

\section{ELLA measurements}

An Enzyme-Linked Lectin Assay (ELLA) was performed to measure influenza $\mathrm{A}$ virus $\mathrm{N}$ activity as described by Couzens, L. et al. ${ }^{3}$. Fetuin-coated plate was prepared by dispense $100 \mu \mathrm{l} /$ well of $25 \mu \mathrm{g} / \mathrm{ml}$ fetuin working solution into each well. The plate was covered and placed at $+4^{\circ} \mathrm{C}$ for 24 hours. Then, the plate was washed 3 times with $200 \mu l$ /well PBS wash buffer for 3 minutes. $100 \mu \mathrm{l}$ sample diluent buffer was added in column 12 as negative control and $50 \mu$ l serial dilution antigen (influenza virus, $\mathrm{N}$ and non-infected allontoic fluid) was transferred from the dilution plate to each well in column 1-11 of the fetuin-coated plate contain an equal volume of sample diluent buffer. The plate was incubated in humidified incubator with $5 \% \mathrm{CO}_{2}$ for 18 hours at $37^{\circ} \mathrm{C}$, and then washed 6 times as described before. $100 \mu \mathrm{l} /$ well PNA-peroxidase was dispensed into each well and incubated at room temperature for 2 hours. After this step, 3 times wash was performed before adding of $100 \mu \mathrm{l} /$ well freshly prepared substrate solution for $10 \mathrm{~min}$ in dark at room temperature. The color reaction was stopped by the addition of $100 \mu \mathrm{l} /$ well stop solution. The plates were read at $490 \mathrm{~nm}$ using 96 -well Automatic plate reader.

\section{Results and Discussion}

\author{
Characterization of synthesized graphene-Au hybrid \\ nanocomposite
}

Fig. 1 demonstrates the SEM images and EDS results of graphene-Au nanocomposite. It can be seen from the Fig. 1 that AuNps are located on the graphene sheets as white dots (average diameter of $250 \mathrm{~nm}$ ). EDS results show that atomic dispersion percentages of graphene-Au nanocomposite are $83.73 \%, 14.97 \%, 1.06 \%$ and mass percentages of these elements $69.29 \%, 14.66 \%$ and $14.32 \%$ for $\mathrm{C}, \mathrm{O}$ and $\mathrm{Au}$, respectively.
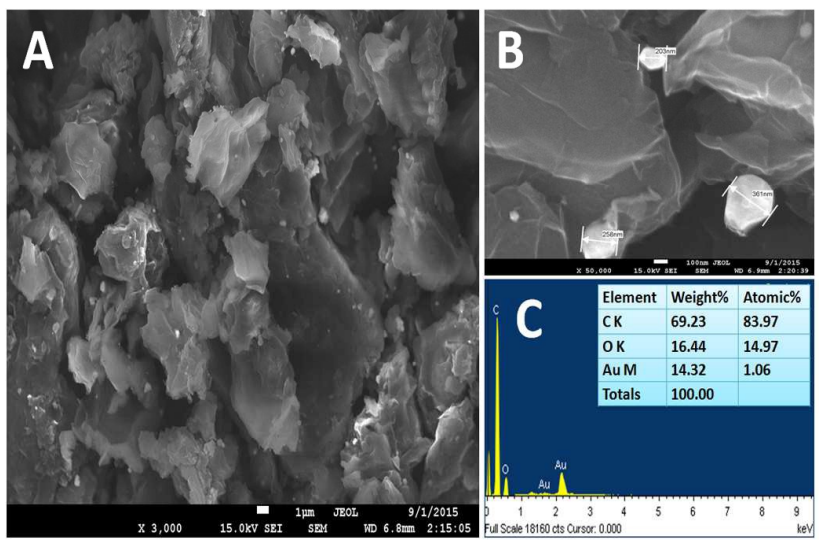

Figure 1. A), B) SEM images of graphene-Au nanocomposite and C) EDS results of graphene-Au nanocomposite.

\section{Electrochemical characterization of developed electrochemical Influenza A biosensor}

The fabrication of developed influenza A biosensor was monitored via EIS in the presence of $10 \mathrm{mM}$ $\mathrm{K}_{3}\left[\mathrm{Fe}(\mathrm{CN})_{6}\right] / \mathrm{K}_{4}\left[\mathrm{Fe}(\mathrm{CN})_{6}\right]$. From the Nyquist plots of EIS (Fig. 2); it can be seen that bare AuSPE has the small semi-circle domain because of high conductivity of Au surface (curve a). After the electrode modification with graphene-Au hybrid nanocomposite, semi-circle domain increases a little bit (curve 
The experimental parameters consisting of the effect of BSA addition on developed system, immobilization time of fetuin $A$, immobilization time of PNA lectin were investigated by EIS. Since developed system is considered to be applied for human samples like throat swabs in future, physiological human $\mathrm{pH}$ and body temperature were chosen as the working conditions so that all the experiments were carried out at $\mathrm{pH} 7.4$ and incubation step of $\mathrm{N}$ was done at $37{ }^{\circ} \mathrm{C}$.

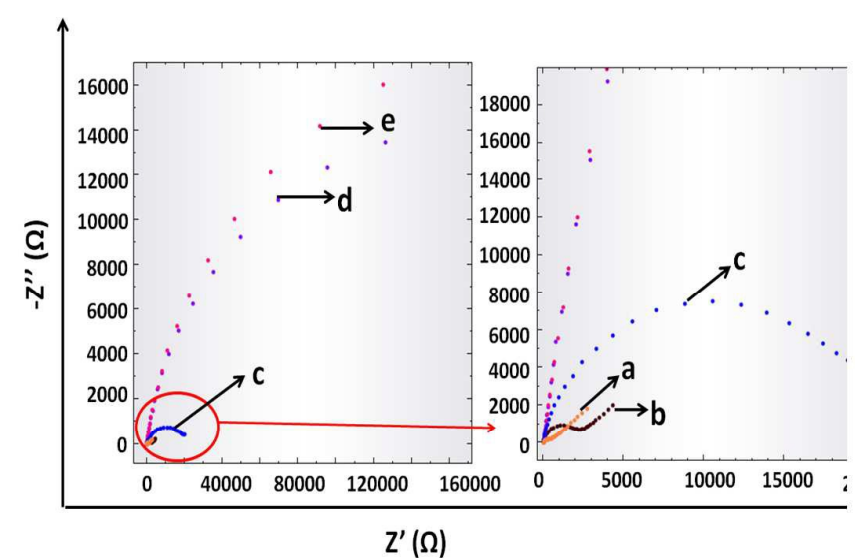

Figure 2. Nyquist plots of developed influenza $A$ viral biosensor. a.Plain AuSPE, b. AuSPE/graphene-AuNp, c. AuSPE/graphene-AuNp/fetuin A, d. AuSPE/grapheneAuNp/fetuin $A / N$, e. AuSPE/graphene-AuNp/fetuin A/N/PNA lectin. The EIS procedure was set to measure the electron transfer resistance in the frequency range of $0.1 \mathrm{~Hz}-10 \mathrm{kHz}$ at potential of $0.1 \mathrm{~V}$ and $10 \mathrm{mM} \mathrm{K}_{3}\left[\mathrm{Fe}(\mathrm{CN})_{6}\right] / \mathrm{K}_{4}\left[\mathrm{Fe}(\mathrm{CN})_{6}\right]$ (in $\mathrm{pH}: 7.4,0.1 \mathrm{M}$ PBS) was used as a redox probe.

The effect of BSA on the developed system

As it is well known, BSA is generally used for the blockage of unspecific interaction on the electrode surface, after the immobilization of the analyte. However, even for this step, it has to be waited for a period of time for the completeness of the attachment of BSA. In order to observe this effect, developed influenza $A$ biosensor was fabricated in the presence of $B S A$, in the absence of BSA and with the simultaneous immobilization of fetuin $A$ at the same time. All these steps were monitored by EIS under the previously mentioned working conditions. The obtained EIS diagrams (Supporting Information, Fig. S1.) demonstrate that for our system there isn't any necessity for BSA addition which means that, there is no unspecific binding during the fabrication of the developed influenza A biosensor. Also by eliminating the addition of BSA, the preparation procedure of biosensor is shortened and as a result, the practicality of the fabrication procedure has been increased. In conclusion, no BSA attachment onto the electrode surface was done for the future experiments.

\section{Optimization of fetuin A immobilization time}

Fetuin A immobilization time experiments were carried out for $15 \mathrm{~min}, 30 \mathrm{~min}, 45 \mathrm{~min}, 60 \mathrm{~min}$ and $90 \mathrm{~min}$ incubation times and the results were monitored by using EIS. The obtained EIS diagrams were presented at the supporting information (Supporting Information, Fig. S2) and the excel plots in it. It can be seen from the Fig. S2. that the best result was obtained at $30 \mathrm{~min}$. Incubation times less than $30 \mathrm{~min}$. results with lower difference in electrode resistance demonstrating that more times are needed probably for the exchange reactions between fetuin A amino groups and NHS to be completed. On the other hand, incubation times more than $30 \mathrm{~min}$, resulted with decrease in resistance difference that might be attributed to the separation of non-specific bonding from the electrode surface. As a result, further experiments were conducted by using $30 \mathrm{~min}$. as the optimum incubation time for fetuin $\mathrm{A}$.

\section{The effect of PNA Lectin immobilization time}

PNA lectin immobilization time experiments were carried out for $30 \mathrm{~min}, 45 \mathrm{~min}, 60 \mathrm{~min}$ and $90 \mathrm{~min}$ immobilization times by using EIS. The obtained EIS diagrams were presented at supporting information (Supporting Information, Fig. S3) and the excel plots were demonstrated in Fig. S3. also. It can be seen from the Fig. S3. that the best result was obtained at 60 min. Immobilization times, less than $60 \mathrm{~min}$. results with lower difference in electrode resistance demonstrating that more times are needed probably for the specific binding reactions between PNA lectin and galactose molecules to be completed. Immobilization times that lasted longer than $60 \mathrm{~min}$, resulted with decrease in resistance difference that might be attributed to the falling out of PNA-galactose structure from the electrode surface ${ }^{11}$. 


\section{Analytical Characteristics}

After the optimization of experimental parameters, the analytical characteristics were examined. For obtaining a calibration graph, the specific interactions between PNA lectin and galactose molecules that occur after the cleavages of $\mathrm{N}$ from the fetuin A were monitored. When the concentration of $\mathrm{N}$ is increased, since more fetuin $\mathrm{A}$ will be cleavage, more galactose molecules will appear and as a result, more PNA lectin will link to the galactose ends. All these changes were monitored via resistance values that were obtained from EIS measurements (Fig. 3.) As you can see from the Fig. 3., the linear range and limit of detection (LOD) values which based on $\mathrm{N}$ concentration was obtained between $10^{-8} \mathrm{U} / \mathrm{mL}$ and $10^{-1}$ $\mathrm{U} / \mathrm{mL}$ with the equations of $\mathrm{y}=2746 \mathrm{x}+31.69\left(\mathrm{R}^{2}=0.99\right)$ and $1 \mathrm{x}$ $10^{-8} \mathrm{U} / \mathrm{mL}$, (stated by brand that 7.9 units $/ \mathrm{mg}$ solid) respectively. Relative standard deviation (R.S.D) value was calculated for $10^{-5} \mathrm{U} / \mathrm{mL} \mathrm{N}(\mathrm{n}=3)$ and found as $3.23 \%$. For the comparison, obtained analytical characteristics values of developed electrochemical biosensor were compared with influenza A virus enzyme-linked immunosorbent (ELISA) assay results in literature. These ELISA assays relied on the $N$ activity or antibody-antigen interaction. From these ELISA assays LOD values such as $0.7 \mathrm{ng} / \mathrm{mL}$ antigen ${ }^{53}, 33 \mathrm{ng} / \mathrm{mL}$ antigen ${ }^{53}, 0.5$ $\mathrm{ng} / \mathrm{mL}$ protein ${ }^{54}$ and $10^{2}-10^{3}$ Tissue Culture Infectious Dose $50 \%$ $\left(\mathrm{TCID}_{50}\right)^{55}$ can be seen. From these results it is obvious that developed sensor is sensitive enough. On the other hand considering rapidity and practicality, it can be said that developed electrochemical biosensor could definitely offer better performances.

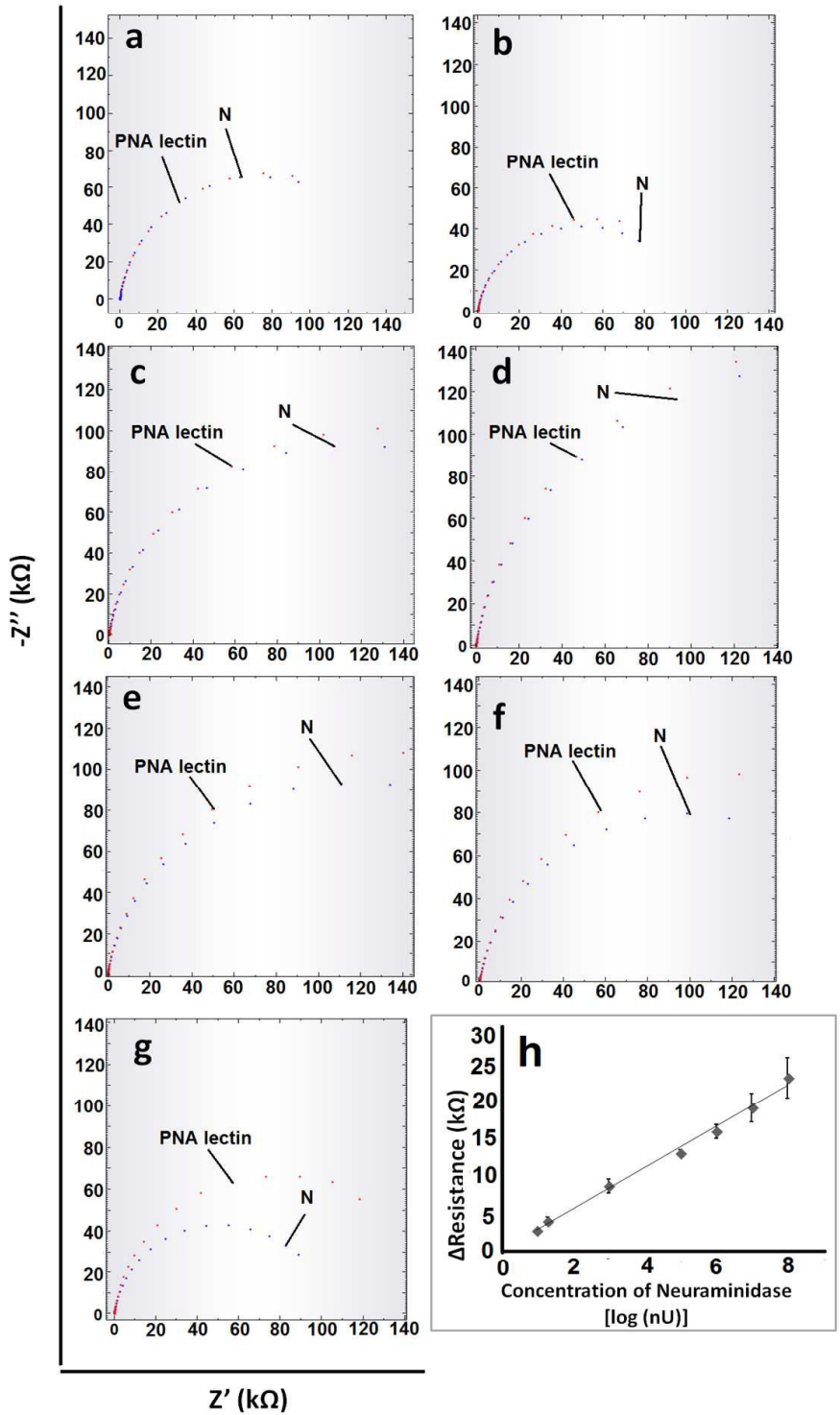

Figure 3. Nyquist plots of different concentration of $\mathrm{N}$; a) 10 ${ }^{8} \mathrm{U} / \mathrm{mL}$, b) $2 \times 10^{-8} \mathrm{U} / \mathrm{mL}$, c) $10^{-6} \mathrm{U} / \mathrm{mL}$, d) $10^{-5} \mathrm{U} / \mathrm{mL}$, e) $10^{-3} \mathrm{U} / \mathrm{mL}$, f) $10^{-2} \mathrm{U} / \mathrm{mL}$ and g) $10^{-1} \mathrm{U} / \mathrm{mL}$; which were used for calibration graph and h)the calibration graph of developed electrochemical influenza virus $A$ biosensor.

\section{Sample application and control studies}

\section{Evaluation of ELLA results}

We developed the electrochemical influenza virus A biosensor which based on $\mathrm{N}$ activity. Therefore, before we applied developed electrochemical influenza virus $A$ biosensor for the real H9N2 influenza type A virus detection, ELLA experiment was carried out to demonstrate that isolated H9N2 influenza type $A$ virus is active according to $\mathrm{N}$ (Supporting Information, Fig. S4). Moreover, ELLA measurements were carried out with 
control group to demonstrate that control group is not active according to $\mathrm{N}$. For this purpose, the ELLA results of H9N2 virus and control group were compared with the ELLA results of standard $\mathrm{N}$. According ELLA results, LOD value of $\mathrm{N}$ was found as $6.52 \times 10^{-6} \mathrm{U} / \mathrm{mL}$. As a result, we also supported the accuracy and sensitivity of the developed influenza virus $A$ biosensors working principle with the ELLA using the same method.

\section{Evaluation of EIS results}

On the other hand, developed and optimized influenza virus $A$ biosensor was applied for real virus detection, H9N2, that was prepared according to the procedure given in experimental part. For this purpose, during the fabrication of electrochemical influenza virus A biosensor, H9N2 influenza virus $\mathrm{A}$ sample was used instead of $\mathrm{N}$. After that, in order to determine the $\mathrm{N}$ activity of H9N2 influenza virus, PNA lectin immobilization step was done.

The control study was also carried out by using uninfected egg sample (allantoic fluid). It can be seen from the Fig. 4. that the developed electrochemical influenza biosensor detects influenza A virus selectively.
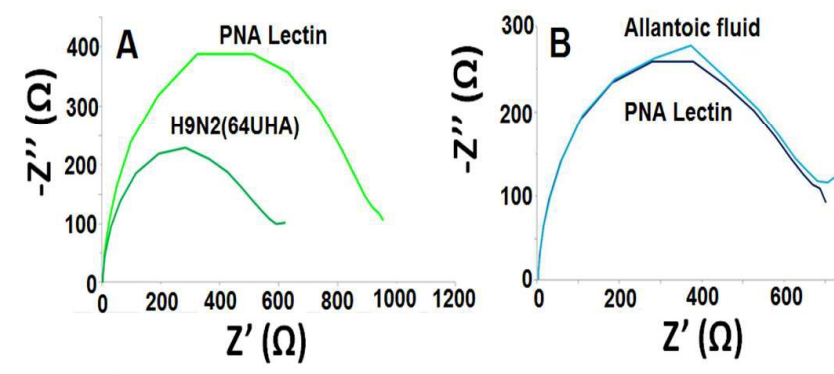

Figure 4. Nyquist plots for A) 64 UHA H9N2 influenza virus, B) control group by using developed electrochemical influenza virus $A$.

\section{Conclusions}

Another novel and effective electrochemical influenza $A$ biosensor based on graphene-Au modified Au-SPE has been developed. This work is the continuation of our previous work where working principle relies on the measurement of $\mathrm{N}$ activity ${ }^{14}$. From the LOD values, it is obvious that with developed electrochemical influenza A biosensor more sensitive results were obtained compared to ELLA assay. We believe that, the wide linear range and sensitive results from real influenza A sample (H9N2) analysis, increase the potential of usage of our system as a point of care tool for the diagnosis of influenza virus $A$ in the future ${ }^{56}$.

\section{Conflicts of interest}

There are no conflicts to declare.

\section{Acknowledgements}

The grant from The Technical and Scientific Council of Turkey (TUBITAK) Project no: $114 Z 654$ is gratefully acknowledged. The Grant from Tunisian Ministry of Higher Education and Scientific Research (MHESRT): Projet Tuniso-Turque 2015-2017.

\section{References}

1 Y. Wu, Y. Wu , B. Tefsen, Y. Shi, G. F. Gao, Trends. Bicrobiol., 2014, 22, 183-191.

2 N. Sriwilaijaroen, Y. Suzuki, Proc. Japan Acad. Ser., 2012, 88, 226-249.

3 L. Couzens, J. Gao, K. Westgeest, M. Sandbulte, V. Lugovtsev, R. Fouchier, M. J. Eichelberger, Virol. Methods 2014, 210, 714.

4 D. R. Peaper, M. L. Landry, Clin. Lab. Med. 2014, 34, 365-385.

5 M. K. Abraham, J. Perkins, G. M. Vilke, C. J. Coyne, The J.of Emerg. Med., 2016, 50, 536-542.

6 C. M. Mair, K. Ludwig, A. Herrmann, C. Sieben, Biochim. Et. Biophys. Acta., 2014, 1838, 1153-1168.

7 J. H. Han, D. Lee, C. H. C. Chew, T. Kim, J. J. Pak, Sens. and Act. B., 2016, 228, 36-42.

8 U. Jarocka, R. Sawicka, A. Gora-Sochacka, A. Sirko, W. Zagorski-Ostoja, J. Radecki, H. Radecka, Biosens. and Bioelectron., 2014, 55, 301-306.

9 S. K. Arya, P. Kongsuphol, C. C. Wong, L. J Polla, M. K. Park, Sens. and Act. B., 2014, 194, 127-133.

10 U. Jarocka, R. Sawicka, A. Gora-Sochacka, A. Sirko, W. Dehaen, J. Radecki, H. Radecka, Sens. and Act. B., 2016, 228, 25-30.

11 L. J. Mitnaul, M. N. Matrosovich, M. R. Castrucci, A. B. Tuzikov, N. V. Bovin, D. Kobasa, Y. Kawaoka, J. of Virol., 2000, 74, 6015-6020.

12 M. N. Matrosovich, T. Y. Matrosovich, T. Gray, N. A. Roberts, H. D. Klenk, J. of Virol., 2004, 78, 12665-12667.

13 J. C. Dortmans, J. Dekkers, I. N. Wickramasinghe, M. H. Verheije, P. J. Rottier, F. J. Van Kuppeveld, E. De Vries, C. A. De Haan, Sci. Rep., 2013, 3, 3058, 1-7.

14 U. Anik, Y. Tepeli, M.F. Diouani, Anal. Chem., 2016, 88, 61516153.

15 J. K. Park, J. K. Taubenberger, ACS Infect. Dis., 2016, 2, 5-7.

16 WHO. Influenza (seasonal); http://www.who.int/mediacentre/ factsheets/fs211/en/ (accessed March 23, 2017).

17 H. Yu, B. J. Cowling, L. Feng, E. H. Lau, Q. Liao, T. K. Tsang, Z. Peng, P. Wu, F. Liu, V. J. Fang, H. Zhang, M. Li, L. Zeng, Z. Xu, Z. Li, H. Luo, Q. Li, Z. Feng, B. Cao, W. Yang, J. T. Wu, Y. Wang, G. M. Leung, The Lancet, 2013, 382, 138-145.

18 L. Krejcova, D. Hynek, V. Adam, J. Hubalek, R. Kizek, Int. J. Electrochem. Sci., 2012, 7, 10779-10801.

19 J. Bell, A. Bonner, D. M. Cohen, R. Birkhahn, R. Yogev, W. Triner, J. Cohen, E. Palavecino, R. Selvarangan, J. Clin. Virol., 2014, 61, 81-86.

20 K. Leirs, P. T. Kumar, D. Decrop, E. Perez-Ruiz, P. Leblebici, B. V. Kelst, G. Compernolle, H. Meeuws, L. V. Wesenbeeck, O. Lagatie, L. Stuyver, A. Gils, J. Lammertyn, D. Spasic, Anal. Chem., 2016, 80, 8450-8458.

21 C. H. Cho, M. K. Woo, J. Y. Kima, S. Cheong, C.-K. Lee, S. A. An, C. S. Lim, W. J. Kim, J. Virol. Methods., 2013, 187, 51-56.

22 L. Chen, Y. Tian, S. Chen, O. Liesenfield, Eur. J. Microbiol. Immunol., 2015, 5, 236-245. 
23 B. Hazelton, T. Gray, J. Ho, V. M. Ratnamohan, D. E. Dwyer, J. Kok, Influenza Other Respir. Viruses., 2015, 9, 151-154.

24 D. E. Sutter, S. A. Worthy, D. M. Hensley, A. M. Maranich, D. M. Dolan, G. W. Fischer, L. T. Daum, J. Med. Virol., 2012, 84, 1699-1702.

25 M. Santhiago, M. Strauss, M. P. Pereira, A.S. Chagas, C. C. B. Bufon, ACS Appl. Mater. Interfaces, 2017, DOI:10.1021/acsami.6b15646.

26 C. Batchelor-McAuley, E. J. F. Dickinson, N. V. Rees, K. E. Toghill, R. G. Compton, Anal. Chem., 2012, 84, 669-684.

27 J. E. Frew, H. A. O. Hill, Anal. Chem., 1987, 59, 933A-944A.

28 Y. Xu, L. Liu, Z. Wang, Z. Dai, ACS Appl. Mater. Interfaces, 2016, 8, 18669-18674.

29 U. Anik, Med. Biosens. for POC Appl. Ed: Roger J Narayan, Woodhead Publishing, Aug 21, 2016, Ch 12, Electrochemical medical biosensors for POC applications 2017, 275-292.

30 C. Zhu, G. Yang, H. Li, D. Du, Y. Lin, Anal. Chem., 2015, 87, 230-249.

31 J. Wang, Analyst, 2005, 130, 421-426.

32 N. Li, X. Su, Y. Lu, , Analyst, 2015, 140, 2916-2943.

33 J. N. Tiwari, V. Vij, K. C. Kemp, K. S. Kim, ACS Nano, 2016, 10, 46-80.

34 Y. Shao, J. Wang, H. Wu, J. Liu, I. A. Aksay, Y. Lin, Electroanalysis, 2010, 22, 1027-1036.

35 S. Wu, Q. He, C. Tan, Y. Wang, H. Zhang, Small, 2013, 9, 1160-1172.

36 X. Gan, H. Zhao, Sens. And Mat., 2015, 27, 191-215.

37 C. Xu, X. Wang, J. Zhu, J. Phys. Chem. C., 2008, 112, 1984119845.

38 Y.Tepeli, U. Anik, Electroanal., 2016, 28, 3048-3054.

39 Z. Zhang, L. Luo, L. Zhu, Y. Ding, D. Deng, Z. Wang, Analyst, 2013,138, 5365-5370

40 S. Aslan, U. Anik, Microchim. Acta., 2016, 183, 73-81.

41 S. C. Sultan, U. Anik, Talanta, 2014, 129, 523-528.

42 M. Giovanni, H. L. Poh, A. Ambrosi, G. Zhao, Z. Sofer, F. Sanek, B. Khezri, R. D. Webster, M. Pumera, Nanoscale 2012, 4, 5002-5008.

43 C. Tan, X. Huang, H. Zhang, Mat. Tod., 2013, 16, 29-36.

44 M. F. Diouani, S. Helali, I. Hafaid, W. M. Hassen, M. A. Snoussi, A. Ghram, N. Jaffrezic-Renault, A. Abdelghani, Met. Sci. and Eng. C., 2008, 28, 580-583.

45 T.L. Kamikawa, M. G. Mikolajczyk, M. Kennedy, P. Zhang, W. Wang, D. E. Scott, E. C. Alocilja, Biosens. and Bioelectron., 2010, 26, 1346-1352.

46 M. Veerapandian, R. Hunter, S. Neethirajan, Talanta, 2016, 155, 250-257.

47 J. Huang, Z. Xie, Z. Xie, S. Luo, L. Xie, L. Huang, Q. Fan, Y. Zhang, S. Wang, T. Zeng, Anal. Chim. Acta, 2016, 913, 121127.

48 Z. Wu, C.H. Zhou, J. J. Chen, C. Xiong, Z. Chen, D.W. Pang, Z.L. Zhang, Biosens. and Bioelectron., 2015, 68, 586-592.

49 W. S. J. Hummers, R. J. Offeman, Am. Chem. Soc., 1958, 80, 1339.

50 D. Li, M. B. Mgller, S. Gilje, R. B. Kaner, G. G. Wallace, Nat. Nanotechnol., 2008, 3, 101-105.

51 S. Stankovich, D. A. Dikin, G. H. Dommett, K. M. Kohlhaas, E. J. Zimney, E. A. Stach, R. D. Piner, S. T. Nguyen, R. S. Ruoff, Nature, 2006, 442, 282-286.

52 Y. Tepeli, U. Anik, Electrochem. Commun. 2015,57, 31-34.

53 W. Honquan, I. Sultana, L. K. Couzens, S. Mindaye, J. Virol. Methods, 2017, 244, 23-28.

54 G. Edevag, M. Eriksson, M. Granström, J. Biol. Stand, 1986, 14, 223-230.

55 S. Velumani, Q. Du, B. j. Fenner, M. Prabakaran, L. C. Wee, L. Y. Nuo, J. Kwang, J. Virol. Methods, 2008, 147, 219-225.

56 Y.Tepeli, U. Anik, Sens. and Act.B, 2018, 254, 377-384. 